DR. YUGEESH RYAN LANKADEVA (Orcid ID : 0000-0002-3589-9111)

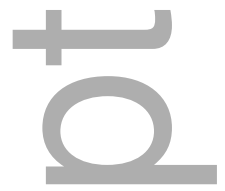

Article type : Invited Reviews

\title{
Sepsis-induced acute kidney injury: A disease of the microcirculation
}

Shuai $\mathrm{Ma}^{1,2}$; Roger G Evans ${ }^{3}$, Naoya Iguchi ${ }^{1,5}$, Marianne Tare ${ }^{3,4}$, Helena C

Parkington $^{3}$, Rinaldo Bellomo ${ }^{6}$, Clive N May ${ }^{1}$, Yugeesh R Lankadeva ${ }^{1}$

${ }^{I}$ Florey Institute of Neuroscience and Mental Health, Melbourne, Victoria, Australia;

${ }^{2}$ Division of Nephrology \& Unit of Critical Nephrology, Shanghai Ninth People's

Hospital, School of Medicine, Shanghai Jiaotong University, Shanghai,

China; ${ }^{3}$ Cardiovascular Disease Program, Biomedicine Discovery Institute and

Department of Physiology, and ${ }^{4}$ Monash Rural Health, Monash University, Victoria,

Australia; ${ }^{5}$ Department of Anesthesiology and Intensive Care Medicine, Graduate

School of Medicine, Osaka University, Osaka, Japan; ${ }^{6}$ School of Medicine,

University of Melbourne, Victoria, Australia

This is the author manuscript accepted for publication and has undergone full peer review but has not been through the copyediting, typesetting, pagination and proofreading process, which may lead to differences between this version and the Version of Record. Please cite this article as doi: 10.1111/micc.12483

This article is protected by copyright. All rights reserved 
Sources of support: YRL was supported by a Future Leader Postdoctoral Fellowship from the National Heart Foundation of Australia (NHF, 101853) and an early career medical research grant from the Jack Brockhoff Foundation.

Running Head: Microcirculation in septic acute kidney injury

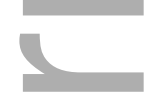

Corresponding author: Yugeesh. Lankadeva (PhD), Florey Institute of Neuroscience and Mental Health, University of Melbourne, Parkville 3010, Victoria, Australia.

Phone: +613 83447302 Email: yugeesh.lankadeva@florey.edu.au

\section{Author Profile}

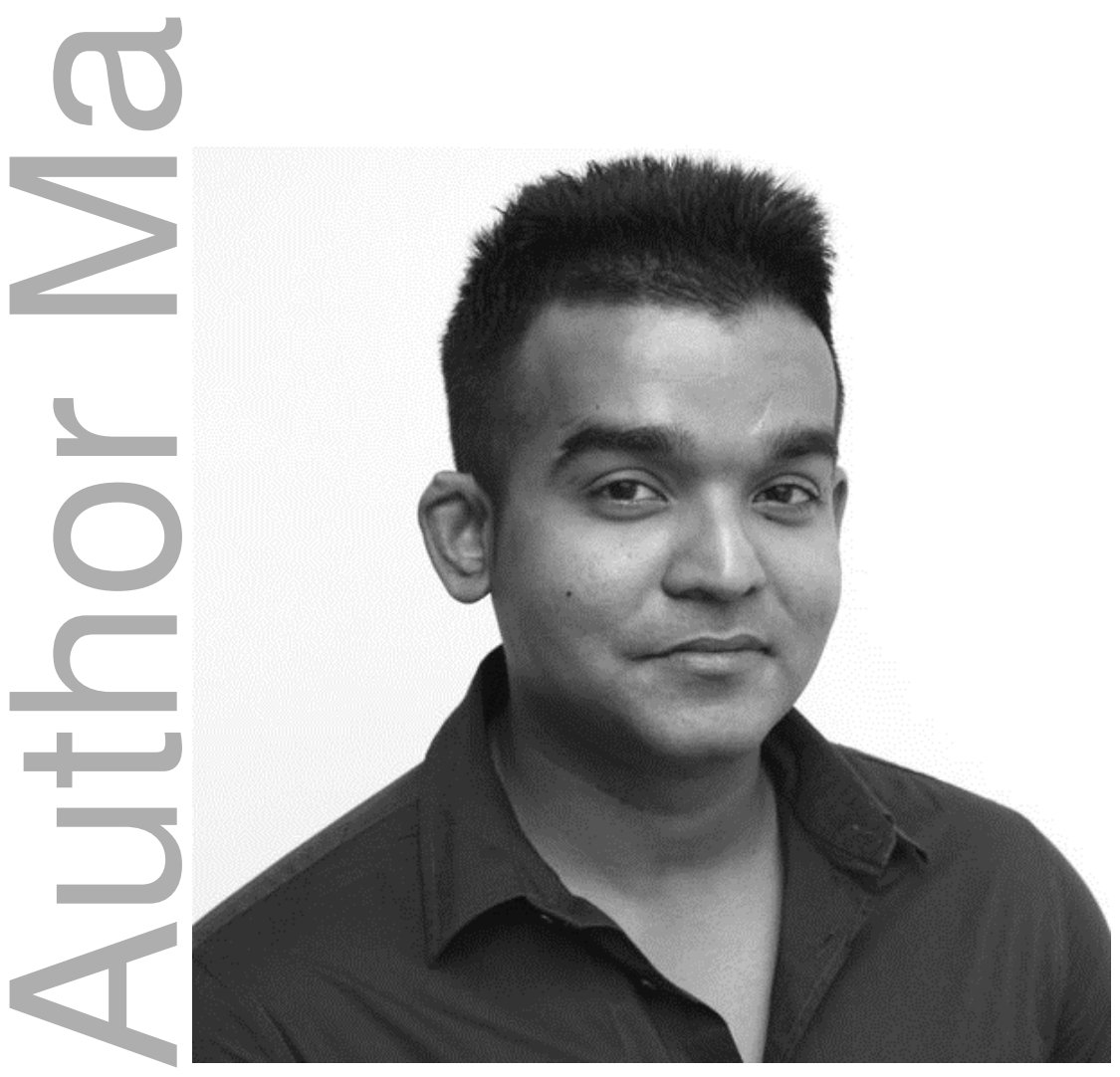

This article is protected by copyright. All rights reserved 
Biography: Yugeesh Lankadeva, Ph.D., is a National Heart Foundation Future Leader Research Fellow in the Pre-Clinical Critical Care Unit at the Florey Institute of Neuroscience and Mental Health. His research focuses on the mechanisms underlying the development of cardiovascular failure and acute kidney injury in sepsis and following cardiac surgery on cardiopulmonary bypass. Dr. Lankadeva is particularly interested in the neurohormonal control of the circulation, from reactivity of isolated blood vessels to integrated physiological studies in the conscious whole animal. His goal is to understand the pathological changes that occur in disease and, armed with this knowledge, to develop improved therapies.

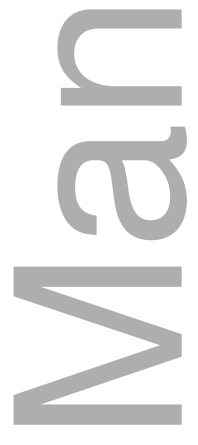

\section{Abstract}

Acute kidney injury (AKI) is a common complication of sepsis and is significantly associated with mortality. Sepsis accounts for more than $50 \%$ of the cases of AKI, with a mortality rate of up to $40 \%$. The pathogenesis of septic AKI is complex, but there is emerging evidence that, at least in the first 48 hours, the defects may be functional rather than structural in nature. For example, septic AKI is associated with an absence of histopathological changes, but with microvascular abnormalities and tubular stress. In this context, renal medullary hypoxia due to redistribution of intra-renal perfusion is emerging as a critical mediator of septic AKI. Clinically, vasopressor drugs remain the cornerstone of therapy for maintenance of blood This article is protected by copyright. All rights reserved 
pressure and organ perfusion. However, in septic AKI there is insensitivity to vasopressors such as norepinephrine, leading to persistent hypotension and organ failure. Vasopressin, angiotensin II and, paradoxically, $\alpha_{2}$-adrenergic receptor agonists (clonidine and dexmedetomidine) may be feasible adjunct therapies for catecholamine-resistant vasodilatory shock. In this review, we outline the recent progress made in understanding how these drugs may influence the renal microcirculation, which represents a crucial step towards developing better approaches for the circulatory management of patients with septic AKI.

Keywords: sepsis; acute kidney injury; hypoxia; vasopressors, $\alpha_{2}$-adrenergic receptor agonists

\section{Introduction}

Sepsis is defined as life-threatening organ dysfunction caused by an overwhelming immune response to infection and is the leading cause of death in intensive care units (ICU) worldwide [101]. The incidence of sepsis in high income countries is approximately 30 million/year and is associated with an annual mortality of 5.3 million/year [42]. Due to the aging population and the increasing number of drug-resistant infections the annual incidence of sepsis continues to rise.

Sepsis is a pathophysiological syndrome characterized by a continuum of severity culminating in septic shock [101]. Septic shock is characterized by refractory This article is protected by copyright. All rights reserved 
hypotension, hyperlactatemia and organ dysfunction that persists after aggressive fluid resuscitation [96]. The transition from sepsis to septic shock and organ failure can occur rapidly, but the mechanisms driving the dysfunction of interconnected organ systems remain unclear. The kidneys are frequently affected by sepsis leading to acute kidney injury (AKI). AKI develops in up to $50 \%$ of patients with sepsis, one-third of whom succumb to this condition [7-9]. The development of AKI in sepsis and septic shock significantly complicates its management and is associated with unfavorable health outcomes. Recent epidemiological studies have generated evidence that survivors of even mild or short episodes of AKI are predisposed to a greater risk of developing chronic and end-stage kidney disease in later life $[24,46,86]$.

Thus, understanding the pathophysiology of septic AKI is important.

Septic AKI is diagnosed as an increase in serum creatinine and/or a decrease in urinary output in the presence of sepsis [11,59]. From an epidemiologic point of view, it is defined by the simultaneous presence of the recent Sepsis-3 consensus criteria for sepsis [101] and the Kidney Disease Improving Global Outcomes (KDIGO) consensus criteria for AKI [59]. Volume resuscitation, vasopressor therapy, antimicrobial therapy and renal replacement therapy remain the mainstays of the management for sepsis-induced AKI in the ICU [96]. Thus, current clinical interventions focus almost entirely on mechanisms upstream from the kidney or are supportive measures aimed at keeping the patient alive in the hope that the kidney will recover. Logically, a better understanding of the pathophysiology of sepsis-induced AKI is essential if we are to develop effective therapies to improve the This article is protected by copyright. All rights reserved 
diagnosis, management, and health outcomes for patients.

\section{Pathophysiology: Renal macro- and microcirculatory alterations}

Macro-circulation: The pathogenesis of septic AKI is complex, and the intra-renal mechanisms driving this disorder are not fully understood. Sepsis is characterized by excessive release of inflammatory mediators, nitric oxide and activated leukocytes, the effects of which culminate in peripheral vasodilation, increased vascular permeability and hypovolemia $[63,78]$. Thus, septic AKI was formerly considered to be a disease of the renal macro-circulation resulting from global renal ischemia, cellular damage and acute tubular necrosis [44,92,99]. However, accumulating evidence from experimental $[23,25,69]$ and clinical studies $[16,84,95]$ has challenged this paradigm by showing that AKI can develop despite maintained or even increased global renal blood flow (RBF) (Figure 1). Moreover, histological assessment of post-mortem kidneys from non-survivors of septic AKI show heterogeneous tubular injury with apical vacuolization, but with an absence of tubular necrosis and minimal apoptosis [76,104]. In a systematic review of 160 studies of experimental sepsis, RBF was shown to be either preserved or elevated in animal models characterized by a hyperdynamic circulation (i.e. increased cardiac output (CO)) [68]. In the absence of a low $\mathrm{CO}$ or low RBF syndrome, in the first 48 hours, such animal models of septic AKI exhibited negligible evidence of histopathological changes [64]. In humans, CO is usually increased at least during the initial stages of sepsis [100]. Similarly, in large This article is protected by copyright. All rights reserved 
animal models, including pigs and sheep, sepsis is associated with a hyperdynamic circulation $[23,25,69]$. Such animal models of hyperdynamic sepsis and AKI, that more closely mimic the human hemodynamic profile, in the first 48 hours, show an absence of acute tubular necrosis and tubular cell apoptosis [67,104]. Moreover, in the clinical setting, AKI develops within the first 24 hours of sepsis in $64 \%$ of patients [8]. These findings suggest that, at least in the first 48 hours, the defects of septic AKI may be functional rather than structural in nature, and potentially reversible [79]. This notion is supported by the experimental findings that renal function rapidly recovers after cessation of Escherichia coli infusion and antibiotic treatment in sheep with severe septic AKI [70].
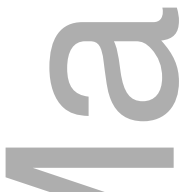

Micro-circulation: Renal tissue hypoperfusion and hypoxia are emerging as critical mediators of the pathogenesis of multiple forms of AKI arising in response to stressors such as cardiac surgery requiring cardiopulmonary bypass, radiocontrast administration, and sepsis $[17,37,38,41]$. In this regard, an increase in global RBF during sepsis does not preclude the possibility of redistribution of intra-renal microcirculatory blood flow, with some portions of the kidney receiving more than adequate perfusion at the expense of others experiencing local tissue ischemia and hypoxia (Figure 1). Germane to such observations, increased heterogeneity of perfusion in the sublingual circulation in humans, due to microcirculatory dysfunction, is a hallmark of septic shock and is associated with a high mortality [30,35,57]. This article is protected by copyright. All rights reserved 
Recently, in conscious sheep with hyperdynamic sepsis and AKI, early onset tissue ischemia and hypoxia selective to the renal medulla has been observed, despite increases in total RBF and whole kidney oxygen delivery [21,71,73]. Indeed, sepsis-induced renal hyperemia was accompanied by increased renal cortical tissue perfusion and oxygenation. These heterogenous changes in regional-kidney perfusion and oxygenation occurred several hours prior to the detection of AKI, as evaluated by the development of oliguria and increased plasma creatinine and urinary neutrophil gelatinase-associated lipocalin $[21,71,73]$. Mechanisms potentially responsible for the redistribution of intra-renal perfusion away from the medulla in sepsis include the excessive release of inflammatory cytokines [2], regional deficits in nitric oxide-mediated vasodilation [54], generation of reactive oxygen and nitrogen species [103], damage to the glycocalyx [86], and disruption to the endothelial barrier [14], all possibly culminating in medullary hypoxia (Figure 1). An early onset of renal medullary tissue hypoxia during sepsis can initiate a vicious cycle of oxidative stress and inflammation that can lead to mitochondrial dysfunction, tubular cell injury, and reduced kidney function (Figure 1) [10,17,37,41,49,61].

Theoretical considerations: Renal tissue oxygenation is determined by the balance between local oxygen delivery and consumption. In the kidney, oxygen delivery is determined not just by total RBF, but also by the distribution of such blood flow to the cortical and medullary circulations [39]. There is also evidence that diffusive shunting of oxygen, between arteries and veins in the cortex and descending and 
ascending vasa recta in the medulla, may further limit oxygen delivery to renal tissue [40]. Oxygen consumption in renal tissue is dominated by the energy requirements of the sodium-potassium ATPase needed to drive tubular sodium reabsorption. Consequently, renal oxygen consumption is directly linked to the filtered load of sodium, and thus glomerular filtration rate [40]. Thus, the effects of goal-directed therapies such as fluid resuscitation and vasopressor drugs on renal tissue oxygenation reflect a complex interaction between their effects on global and regional kidney tissue blood flow and tubular function. Importantly, any therapy that increases glomerular filtration rate would be expected to increase renal oxygen consumption and in turn, potentially promote renal tissue hypoxia. Thus, the implementation of current therapies for patients with septic AKI, and the development of new interventions, must begin with recognition of RBF-dependent oxygen demand on the renal microcirculation.

\section{Hemodynamic management of septic shock and acute kidney injury}

Fluids: Central hemodynamic support with aggressive fluid bolus therapy $(20 \mathrm{~mL} / \mathrm{Kg}$ ) is the recommended first-line approach for patients with sepsis and septic AKI and is believed to improve renal perfusion and oxygenation by correcting hypovolemia [96]. Experimental studies in hemorrhagic and endotoxemic rats, however, have failed to demonstrate any improvement in renal cortical or medullary tissue oxygenation in response to fluid resuscitation $[1,56,75]$. However, such rodent models of sepsis were characterized by a hypodynamic circulation, thus confounding septic shock with 
simultaneous cardiogenic shock. Recent multicenter randomized trials using aggressive fluid-based resuscitation strategies have also failed to show any improvement in renal outcomes or mortality $[83,88,109]$. Moreover, evaluation of renal functional indices in patients with sepsis revealed no beneficial effects of aggressive fluid bolus therapy on the incidence and progression of AKI [60]. Thus, the mechanisms by which fluid resuscitation might influence the renal macro- and microcirculation must be carefully evaluated in animal models of hyperdynamic sepsis and AKI that more closely mimic the human septic phenotype to develop effective evidence-based interventions. In septic shock, if fluid resuscitation fails to adequately correct the underlying hypotension, organ hypoperfusion, and hyperlactatemia, clinicians are then faced with the need to implement vasopressor therapy.
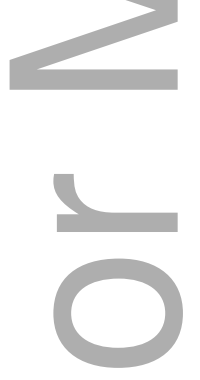

\section{Vasopressor Therapy}

Norepinephrine: In septic shock, norepinephrine is the first-choice vasopressor recommended to restore mean arterial blood pressure to $\geq 65 \mathrm{mmHg}$ [96], and potentially even to levels above $80 \mathrm{mmHg}$ in patients with pre-existing hypertension [5]. Norepinephrine increases arterial pressure by $\alpha$-adrenergic receptor-mediated vasoconstriction, with a small $\beta$-adrenergic receptor-mediated increase in stroke volume and thus $\mathrm{CO}[51,91]$. The renal benefits of using norepinephrine in septic AKI 
remain controversial due to the fear of it inducing further deterioration in renal function by causing localized renal vasoconstriction and ischemia [12,51,91]. However, norepinephrine therapy has been shown to consistently reverse hypotension and transiently improve renal function in septic shock, as evaluated by estimated glomerular filtration rate, with fewer adverse effects than dopamine, vasopressin, epinephrine, or phenylephrine $[29,81,85,98]$. These findings, amongst others, have provided the clinical basis for administering norepinephrine as the primary vasopressor therapy in septic shock.

A major unresolved clinical problem encountered during the treatment of septic shock is that $15-20 \%$ of patients become unresponsive to norepinephrine $[63,66,78]$. In the setting of refractory septic shock, high doses of norepinephrine $(0.5-1.0 \mu \mathrm{g} / \mathrm{kg} / \mathrm{min})$ [18] are required to attain target blood pressure, and this is associated with a substantially increased mortality rate, ranging from 60 to $100 \%[6,18]$. The high mortality rate associated with catecholamine-resistant septic shock can be attributed to refractory hypotension leading to reduced organ perfusion and organ failure and/or to direct adverse effects of the high levels of catecholamines and their metabolites on organ systems $[58,61,72]$. Several mechanisms are proposed to account for the pathogenesis of refractory hypotension in septic shock, including increased activity of vasodilators such as nitric oxide and prostanoids, an excessive opening of ATP-sensitive potassium channels, metabolic acidosis and increased levels of inflammatory cytokines $[63,66,78]$. Together, these mechanisms can lead to loss of 
vascular tone and hypo-responsiveness to vasopressors, causing severe hypotension, organ hypoperfusion, and potentially multiple-organ failure and death.

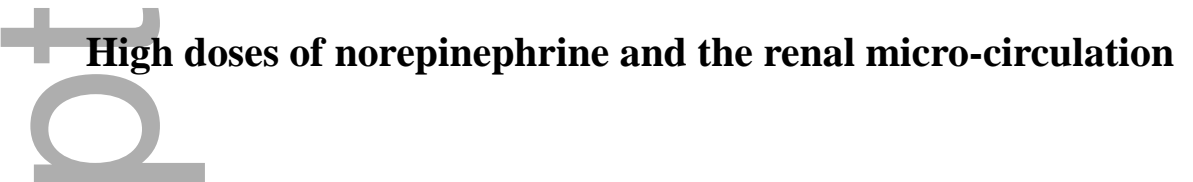

Emerging experimental and clinical evidence demonstrate that there is "uncoupling" between the macro- and micro-circulation in response to vasoactive drugs in healthy and pathological states in non-renal and renal tissues. In a porcine model of septic shock, resuscitation with norepinephrine worsened microcirculatory flow abnormalities within the mesenteric circulation [65]. Similarly, there is clinical evidence that restoration of systemic hemodynamics with norepinephrine does not improve microcirculatory abnormalities in septic shock, as assessed by measurement of sublingual blood flow $[30,35,55]$. In the context of the renal microcirculation, it is becoming evident from experimental studies that alterations in regional-kidney perfusion and oxygenation cannot be reliably predicted from the assessment of global RBF and whole kidney oxygen delivery $\left(\mathrm{RDO}_{2}\right)$. In healthy sheep, intravenous infusion of norepinephrine dose-dependently reduced both renal cortical and medullary tissue oxygenation, despite preserved $\mathrm{RBF}$ and $\mathrm{RDO}_{2}$ [20]. In septic sheep with established AKI, restoration of blood pressure with clinically relevant high doses of norepinephrine $(0.4-0.8 \mu \mathrm{g} / \mathrm{kg} / \mathrm{min})$ exacerbated the underlying renal medullary ischemia and hypoxia (Figure $2 \& 3$ ) [73]. These intra-renal changes also occurred independently of changes in $\mathrm{RBF}$ and $\mathrm{RDO}_{2}$ in response to norepinephrine infusion in septic sheep (Figure 3) [73]. The long-term consequences for renal outcomes of this This article is protected by copyright. All rights reserved 
exaggerated renal medullary ischemia and hypoxia, induced by high doses of norepinephrine in sepsis, are unknown and warrant further investigation. Accumulating clinical evidence indicates that most survivors of AKI are at a greater risk of developing progressive chronic kidney disease and end-stage kidney disease in later life, which are well known risk factors for major cardiovascular diseases such as heart failure, myocardial infarction and stroke $[24,46,86]$. This provides the rationale for evaluating catecholamine-sparing strategies for septic shock that do not worsen the underlying pathological and reparative processes that occur during AKI.

\section{Catecholamine-sparing strategies for septic shock and acute kidney injury}

Vasopressin: Vasopressin is currently recommended as a rescue vasopressor for patients who are unresponsive to norepinephrine and/or for reducing the dose of norepinephrine required to attain target blood pressure [96]. Vasopressin increases arterial blood pressure chiefly by stimulating $\mathrm{V}_{1}$ receptors located on vascular smooth muscle cells to induce vasoconstriction, and also by preventing the excessive opening of ATP-sensitive potassium channels in septic shock [97]. In the Vasopressin and Septic Shock-Trial (VASST), mortality was not reduced by low-dose vasopressin (17-50 $\mathrm{ng} / \mathrm{min})$ therapy compared with high doses of norepinephrine $(5-15 \mu \mathrm{g} / \mathrm{min})$ [98]. However, a subgroup analysis of the VASST trial showed lower incidences of progression of septic AKI and mortality within the vasopressin treatment group [45]. Moreover, patients treated with vasopressin had greater improvements in urinary output and glomerular filtration rate than those treated with norepinephrine alone [45]. 
Similarly, in ovine septic AKI, low dose vasopressin (33 ng/min) has been reported to restore blood pressure and significantly improve renal function [34]. In healthy conscious sheep, infusion of vasopressin preserved renal cortical and medullary tissue perfusion and oxygenation [20]. Within the renal vasculature, the magnitute of the $\mathrm{V}_{1}$ receptor-mediated vasoconstriction by vasopressin has been demonstrated to be effectively modulated by vasodilator systems, such as nitric oxide and eicosanoids, specially in the renal cortex [27,93]. This may explain the better maintenance of intra-renal perfusion and oxygenation in response to treatment with vasopressin when compared with norepinephrine in healthy sheep [20]. Together, these findings suggest that vasopressin at lower doses may offer a degree of renoprotection in the setting of septic AKI compared with high doses of norepinephrine alone. However, vasopressin at higher dose ranges (>83 $\mathrm{ng} / \mathrm{min}$ ) has been showed to induce myocardial, digital and mesenteric ischemia $[31,97]$ and thus such doses should be avoided.

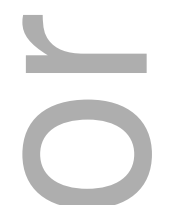

Angiotensin II: Angiotensin II is potent vasoconstrictor acting via angiotensin type 1 receptors to increase arterial pressure [47]. In early ovine hyperdynamic sepsis, angiotensin II effectively restored arterial pressure and caused greater improvements in renal function than norepinephrine alone $[33,108]$. In septic sheep and pigs, angiotensin II restored systemic hemodynamics without deleterious effects on other vital organs, biochemical variables or renal bioenergetics and also no further increases in arterial blood lactate or inflammatory cytokines $[25,80,108]$. In a pilot study in This article is protected by copyright. All rights reserved 
patients with catecholamine-resistant septic shock, angiotensin II effectively restored blood pressure and doubled renal function [22].

The beneficial renal functional effects of angiotensin II in septic AKI may be due to its ability to induce a more profound increase in post-glomerular resistance compared with the pre-glomerular resistance, thus increasing glomerular perfusion pressure and filtration rate [32]. Importantly, angiotensin II has also been demonstrated to play an important role in resetting the lower limit of renal autoregulation, especially at lower renal perfusion pressures $[28,52,102]$. Together, these features of Ang II may account for its ability to maintain autoregulation of GFR, relative to RBF, at a reduced renal perfusion pressure in settings of systemic hypotension such as septic shock. In septic pigs, intravenous infusion of angiotensin II for 48-hours did not have any adverse effects on mitochondrial respiration in the kidney, heart or liver when compared with norepinephrine treatment [25]. After these initial safety and feasibility studies, a randomized, double-blinded, multicenter clinical trial in more than 300 patients with catecholamine-refractory vasodilatory shock validated angiotensin II as an effective rescue vasopressor to restore blood pressure (Angiotensin II for Treatment of High Output Shock (ATHOS)) [62]. Following the ATHOS trial, angiotensin II was approved for treatment of high output vasodilatory shock for humans by the U.S. Food and Drug Administration in December 2017. However, angiotensin II is currently not recommended as a primary vasopressor in septic shock due to its potential inflammatory and thrombotic actions, which may aggravate microcirculatory 
dysfunction $[4,26]$. Further clinical investigations are required to determine the role of angiotensin II as a first-choice vasopressor therapy for vasodilatory shock, to identify the patients that are most likely to benefit and to further establish its safety.

In healthy conscious sheep, infusion of angiotensin II did not reduce renal cortical or medullary perfusion, which was in contrast to the intra-renal vasoconstrictor effects seen with norepinephrine [20]. In a recent study of established ovine septic AKI, angiotensin II used as a primary vasopressor was shown to effectively restore blood pressure and transiently increase renal function, in a manner similar to that seen during infusion of norepinephrine (Figure 2) [71,73]. Importantly, angiotensin II restored systemic hemodynamics and renal function without further compromising renal medullary perfusion and oxygenation, which occurred with norepinephrine (Figure $2 \& 3$ ) [71,73]. Indeed, a subgroup analysis of the ATHOS trial involving 105 patients with septic AKI on renal replacement therapy at randomization showed a $23 \%$ relative reduction in risk of mortality and a more rapid recovery of renal function when angiotensin II (compared to placebo) was used as an adjunct therapy [107]. Together, these experimental and clinical findings suggest that angiotensin II may be a safer alternative primary vasopressor agent in the setting of septic AKI.

$\alpha_{2}$-adrenergic receptor agonists: Dexmedetomidine and clonidine are routinely used as sedatives to reduce agitation and delirium in critically ill patients in ICUs $[89,94]$. Such so-called 'centrally-acting $\alpha_{2}$-agonists' mainly act on the pre-synaptic $\alpha_{2}$-adrenergic receptors to inhibit norepinephrine release from both central and This article is protected by copyright. All rights reserved 
peripheral nerve terminals, thereby reducing overall sympathetic nerve activity [83]. Of relevance, administration of high doses of vasopressin (100 ng) directly into the area postrema has also been demonstrated to augment baroreflex-mediated inhibition of renal and lumbar sympathetic nerve activity in rodents [48].

High plasma norepinephrine levels have been reported in non-survivors compared with survivors in a population of critically ill patients [15]. High levels of endogenous norepinephrine were also significantly associated with mortality in patients with septic shock [13]. Thus, the centrally acting sympatholytic actions of $\alpha_{2}$-adrenergic receptor agonists may improve prognosis by reducing the adverse effects of sympathetic overstimulation in septic shock. However, the use of centrally acting sympatholytics in the treatment of a hypotensive condition such as septic shock raises concerns because of their actions to reduce sympathetic nerve activity, which would be expected to enhance the degree of hypotension in septic shock and promote multi-organ failure. However, authors of studies in rodent models of sepsis have reported improved survival rates with dexmedetomidine and clonidine treatment $[50,105,106]$. In agreement, authors of clinical studies have also reported $8 \%$ and $20 \%$ reductions in risk of mortality in patients with septic shock following dexmedetomidine therapy $[58,87]$.

A possible mechanism underlying the beneficial effects of $\alpha_{2}$-adrenergic receptor agonists was revealed by the recent finding that these drugs reverse vascular hypo-responsiveness in septic shock [43,72]. Indeed, experimental studies using This article is protected by copyright. All rights reserved 
supra-therapeutic doses of clonidine $(200 \mu \mathrm{g} / \mathrm{kg})$ or dexmedetomidine $(100 \mu \mathrm{g} / \mathrm{kg})$ showed restoration of pressor responsiveness to norepinephrine in endotoxemic rats [43]. It has been proposed that this beneficial effect of $\alpha_{2}$-adrenergic receptor agonists is due to a reduction in sympathetic outflow leading to up-regulation of vascular smooth muscle $\alpha_{1}$-adrenergic receptors that were otherwise down-regulated in sepsis. More recently, these findings in rodents were validated in an ovine model of hyperdynamic sepsis, in which infusion of a clinically-relevant dose of clonidine (1 $\mu \mathrm{g} / \mathrm{kg} / \mathrm{h}$ ) reduced the high levels of renal sympathetic nerve activity and restored pressor responsiveness to phenylephrine (Figure 4) [72]. In accord with these findings, two recent case reports showed that infusion of the same dose of clonidine $(1 \mu \mathrm{g} / \mathrm{kg} / \mathrm{h})$ reduced the dose of norepinephrine required to maintain blood pressure by $45 \%$ in a patient with terminal pulmonary septic shock [90] and by $90 \%$ in a neonate with necrotizing enterocolitis [77]. Interestingly, in ovine hyperdynamic sepsis, clonidine also restored sensitivity to a non-adrenergic receptor vasoconstrictor (angiotensin II) [72]. These findings suggest that the actions of $\alpha_{2}$-adrenergic receptor agonists to improve pressor responsiveness in septic shock may result from mechanisms that are either downstream or independent of $\alpha_{1}$-adrenergic receptors. Previously, in vitro functional studies in healthy rodents have demonstrated a potential synergism between the post-junctional angiotensin type 1 receptors and $\alpha_{2}$-adrenergic receptor agonists to potentiate vascular resistance $[53,74]$. This interaction may be of relevance to the studies in ovine hyperdynamic sepsis that demonstrate a complete restoration in pressor responsiveness to angiotensin II following treatment with the $\alpha_{2}$-agonist, This article is protected by copyright. All rights reserved 
clonidine. However, further studies in clinically relevant models of sepsis are required to define the precise intra-cellular mechanisms involved.

There is a paucity of experimental and clinical data regarding the effects of $\alpha_{2}$-adrenergic receptor agonists on the renal microcirculation in the setting of septic

AKI. In rodent models of sepsis, clonidine, and dexmedetomidine appear to improve renal function and outcomes $[50,105,106]$. In an ovine model of hyperdynamic sepsis and AKI, infusion of clonidine $(1 \mu \mathrm{g} / \mathrm{kg} / \mathrm{h})$ reduced the degree of global renal hyperemia and doubled urinary output [19]. However, this diuretic response was dissociated from any changes in creatinine clearance or fractional excretion of sodium [19]. Similarly, a clinical study showed that renal function as indirectly estimated by serum creatinine, was neither superior nor inferior as a consequence of dexmedetomidine treatment in patients with septic shock [58]. Considering the experimental evidence that restoration of blood pressure with high doses of norepinephrine has unfavorable effects on renal medullary perfusion and oxygenation in septic AKI (Figures 2 \& 3) [73], reducing vasopressor requirements with $\alpha_{2}$-adrenergic receptor agonists may be a feasible strategy for minimizing the harmful effects of high levels of catecholamines on the renal microcirculation. Indeed, reducing doses of norepinephrine in septic shock is likely to have multiple other benefits considering the evidence that high doses of catecholamines and their metabolites lead to many adverse events. These deleterious effects include reductions in immune function and metabolic efficiency, stimulation of bacterial growth, 
increases in pulmonary artery pressure and increased mortality $[3,36,82]$.

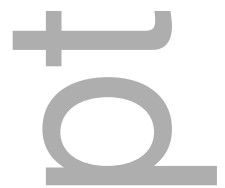

\section{Perspectives}

The renal medulla appears to be particularly susceptible to ischemia and hypoxia in multiple forms of AKI, including septic shock. Indeed, renal tissue hypoxia due to redistribution of intra-renal perfusion is emerging as a critical pathophysiological aspect of septic AKI. High doses of norepinephrine appear to have deleterious effects on the renal microcirculation in healthy and pathophysiological states. Thus, vasopressor therapies aimed at restoring arterial pressure and renal function in septic AKI should be administered with caution, and with consideration of their effects on intrarenal tissue perfusion and oxygenation. Global kidney blood flow and whole kidney oxygen delivery appear to be poor predictors of regional-kidney perfusion and oxygenation. Thus, it is important that future experimental studies directly monitor the effects of new therapies on the renal microcirculation. Recent experimental studies demonstrating adverse effects of high-doses of catecholamines on the renal microcirculation in septic AKI provides the impetus to explore the benefit of non-catecholamine vasopressor drugs, such as vasopressin and angiotensin II, and catecholamine-sparing interventional strategies, such as $\alpha_{2}$-adrenergic receptor agonists. However, it is important to be certain that new treatments do not worsen the underlying pathological processors that occur in septic AKI. Therapies that preserve renal medullary tissue perfusion and oxygenation in the early stages of sepsis may This article is protected by copyright. All rights reserved 
bring new hope towards reducing the development and/or progression of AKI and improving the health outcomes of these critically ill patients.

\section{FIGURE LEGENDS:}

Figure 1: Potential pathways implicated in the pathogenesis of acute kidney injury in animal models of hyperdynamic sepsis that are characterized by either increased or preserved renal blood flow (RBF).

Figure 2: In septic sheep with established acute kidney injury, restoring blood pressure with noradrenaline worsened medullary tissue hypoxia, an effect not seen with angiotensin II.

Time 0 is the mean of the $24^{\text {th }}$ hour of the baseline period, and times 24 to 30 hours are means of 1-hour periods during infusion of live Escherichia coli and treatment with norepinephrine $(n=7)$ or angiotensin II $(n=7)$ or saline $(n=7)$. Data are between animal mean \pm SEM. Figure modified from Refs [71 \& 73].

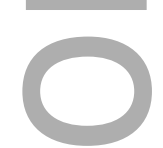

Figure 3: Schematic highlighting the differential effects on the renal macro- and micro-circulatory perfusion and oxygenation in response to resuscitation with norepinephrine and angiotensin II in septic sheep with hyperdynamic sepsis and established acute kidney injury. A: Noradrenaline Therapy: Further exacerbated the renal medullary ischemia and hypoxia in septic acute kidney injury, despite no significant effects on global renal blood flow, renal oxygen delivery, cortical 
perfusion, and oxygenation. B: Angiotensin II Therapy: Reduced the degree of global renal hyperemia in septic acute kidney injury but had no significant effects on renal cortical and medullary perfusion and oxygenation. Results modified from Refs $[71 \&$ 73].

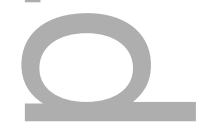

Figure 4: In conscious septic sheep with established hypotension, clonidine improved mean arterial pressure (MAP) and reduced renal sympathetic nerve activity (RSNA) (left panels). Pressor responsiveness to phenylephrine (PE) was reduced at $24 \mathrm{~h}$ of sepsis compared to healthy sheep (control) and was restored to pre-morbid levels by $8 \mathrm{~h}$ of clonidine treatment ( $32 \mathrm{~h}$ of sepsis) (right panels).

Time 0 is the mean of the $24^{\text {th }}$ hour of the baseline period, and times 24 to 32 hours are means of 1-hour periods during infusion of live Escherichia coli and treatment with clonidine $(n=6)$ or saline $(n=6)$. Data are between animal mean $\pm S E M$. $P$ values represent treatment-time interactions from two-way repeated measures ANOVA. Figure modified from Ref [72].

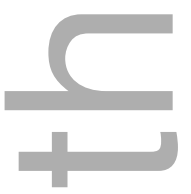

\section{References}

1. Aksu U, Bezemer R, Yavuz B, Kandil A, Demirci C, Ince C. Balanced vs unbalanced crystalloid resuscitation in a near-fatal model of hemorrhagic shock and the effects on renal oxygenation, oxidative stress, and inflammation. Resuscitation $\mathbf{8 3}$ : 767-773, 2012. 
2. Alves-Filho JC, Sonego F, Souto FO, Freitas A, Verri WA, Auxiliadora-Martins M, Basile-Filho A, McKenzie AN, Xu D, Cunha FQ, Liew FY. Interleukin-33 attenuates sepsis by enhancing neutrophil influx to the site of infection. Nat Med 16: 708-712, 2010.

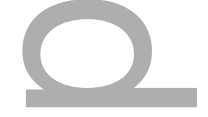

3. Andreis DT, Singer M. Catecholamines for inflammatory shock: a Jekyll-and-Hyde conundrum. Intensive Care Med 42: 1387-1397, 2016.

4. Antonucei E, Gleeson P, Annoni F, Agosta S, Orlando S, Taccone F, Velissaris D, Scolletta S. Angiotensin II in refractory septic shock. Shock 47: 560-566, 2016.

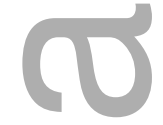

5. Asfar P, Meziani F, Hamel J-F, Grelon F, Megarbane B, Anguel N, Mira J-P, Dequin P-F, Gergaud S, Weiss N, Legay F, Le Tulzo Y, Conrad M, Robert R, Gonzalez F, Guitton C, Tamion F, Tonnelier J-M, Guezennec P, Van Der Linden T, Vieillard-Baron A, Mariotte E, Pradel G, Lesieur O, Ricard J-D, Hervé F, du Cheyron D, Guerin C, Mercat A, Teboul J-L,

Radermacher P. High versus low blood-pressure target in patients with septic shock. New England Journal of Medicine 370: 1583-1593, 2014.

6. Auchet T, Regnier M, Girerd N, Levy B. Outcome of patients with septic shock and high-dose vasopressor therapy. Ann Intensive Care 7: 43, 2017. 
7. Bagshaw SM, George C, Bellomo R, the ADMC. Early acute kidney injury and sepsis: a multicentre evaluation. Crit Care 12: R47-R47, 2008.

8. Bagshaw SM, Lapinsky S, Dial S, Arabi Y, Dodek P, Wood G, Ellis P, Guzman J, Marshall J, Parrillo JE, Skrobik Y, Kumar A. Acute kidney injury in septic shock: clinical outcomes and impact of duration of hypotension prior to initiation of antimicrobial therapy. Intensive Care Med 35: 871-881, 2009.

9. Bagshaw SM, Uchino S, Bellomo R, Morimatsu H, Morgera S, Schetz M, Tan I, Bouman C, Macedo E, Gibney N, Tolwani A, Oudemans-van Straaten HM, Ronco C, Kellum JA, Beginning ft, Investigators ESTftK. Septic acute kidney injury in critically ill patients: Clinical characteristics and outcomes. Clin J Am Soc Nephrol 2: 431-439, 2007.

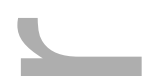

10. Bellomo R, Kellum JA, Ronco C, Wald R, Martensson J, Maiden M, Bagshaw SM, Glassford NJ, Lankadeva YR, Vaara ST, Schneider A. Acute kidney injury in sepsis. Intensive Care Med 43: 816-828, 2017.

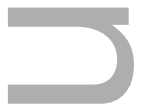

11. Bellomo R, Ronco C, Kellum J, Mehta R, Palevsky P, workgroup ADQI. Acute renal failure - definition, outcome measures, animal models, fluid therapy and information technology needs: the Second International Consensus Conference of the Acute Dialysis Quality Initiative (ADQI) Group. Crit Care 8: R204-212, 2004.

This article is protected by copyright. All rights reserved 
12. Bellomo R, Wan L, May C. Vasoactive drugs and acute kidney injury. Critical Care Medicine 36: S179-S186, 2008.

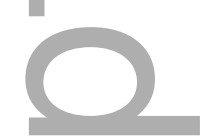

13. Benedict C, Rose J. Arterial norepinephrine changes in patients with septic shock.

Circ Shock 38: 165-172, 1992.

14. Blum MS, Toninelli E, Anderson JM, Balda MS, Zhou J, O'Donnell L, Pardi R, Bender JR. Cytoskeletal rearrangement mediates human microvascular endothelial tight junction modulation by cytokines. Am J Physiol Heart Circ Physiol 273: H286-H294, 1997.

15. Boldt J, Menges T, Kuhn D, Diridis C, Hempelmann G. Alterations in circulating vasoactive substances in the critically ill--a comparison between survivors and non-survivors. Intensive Care Med 21: 218-225, 1995.

16. Breñner M, Schaer GL, Mallory DL, Suffredini AF, Parrillo JE. Detection of renal blood flow abnormalities in septic and critically ill patients using a newly designed indwelling thermodilution renal vein catheter. Chest 98: 170-179, 1990.

17. Brezis M, Rosen S. Hypoxia of the renal medulla - Its implications for disease. N Engl J Med 332: 647-655, 1995.

This article is protected by copyright. All rights reserved 
18. Brown SM, Lanspa MJ, Jones JP, Kuttler KG, Li Y, Carlson R, Miller RR, Hirshberg EL, Grissom CK, Morris AH. Survival after shock requiring high-dose vasopressor therapy. Chest 143: 664-671, 2013.

19. Calzavacca P, Booth L, Lankadeva Y, Bailey S, Burrell L, Bailey M, Bellomo R, May C. Effects of clonidine on the cardiovascular, renal and inflammatory responses to experimental bacteremia. Shock doi: 10.1097/SHK.0000000000001134, 2018.

20. Calzavacca P, Evans R, Bailey M, Bellomo R, May C. Variable responses of regional renal oxygenation and perfusion to vasoactive agents in awake sheep. Am J Physiol Regul Integr Comp Physiol 309: R1226-1233, 2015.

21. Calzavacca P, Evans RG, Bailey M, Bellomo R, May CN. Cortical and medullary tissue perfusion and oxygenation in experimental septic acute kidney injury. Crit Care Med 43: e431-439, 2015.

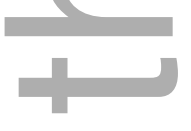

22. Chawla LS, Busse L, Brasha-Mitchell E, Davison D, Honiq J, Alotaibi Z, Seneff MG. Intravenous angiotensin II for the treatment of high-output shock (ATHOS trial): a pilot study. Crit Care 18: 534, 2014.

23. Chvojka J, Sykora R, Krouzecky A, Radej J, Varnerova V, Karvunidis T, Hes O, This article is protected by copyright. All rights reserved 
Novak I, Radermacher P, Matejovic M. Renal haemodynamic, microcirculatory, metabolic and histopathological responses to peritonitis-induced septic shock in pigs. Crit Care 12: R164-R164, 2008.

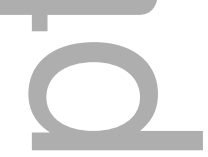

24. Coca SG, Yusuf B, Shlipak MG, Garg AX, Parikh CR. Long-term risk of mortality and other adverse outcomes after acute kidney injury: a systematic review and meta-analysis. Am J Kidney Dis 53: 961-973, 2009.

25. Corrêa TD, Jeger V, Pereira AJ, Takala J, Djafarzadeh S, Jakob SM. Angiotensin II in septic shock: effects on tissue perfusion, organ function, and mitochondrial respiration in a porcine model of fecal peritonitis. Crit Care Med 42: e550-559, 2014.

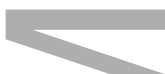

26. Corrêa TD, Takala J, Jakob SM. Angiotensin II in septic shock. Crit Care 19: 98, 2015.

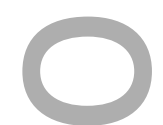

27. Cowley A, Skelton M, Kurth T. Effects of long-term vasopressin receptor stimulation on medullary blood flow and arterial pressure. Am J Physiol 275: R1420-1424, 1998.

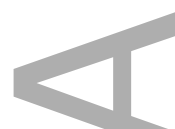

28. Cupples WA. Angiotensin II conditions the slow component of autoregulation of renal blood flow. Am J Physiol Renal Physiol 264: F515-F522, 1993. 
29. De Backer D, Aldecoa C, Njimi H, Vincent J-L. Dopamine versus norepinephrine in the treatment of septic shock: A meta-analysis*. Crit Care Med 40: 725-730, 2012.

30. De Backer D, Donadello K, Sakr Y, Ospina-Tascon G, Salgado D, Scolletta S, Vincent J-L. Microcirculatory alterations in patients with severe sepsis: Impact of time of assessment and relationship with outcome*. Crit Care Med 41: 791-799, 2013.

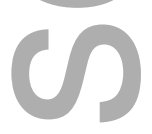

31. Dellinger RP, Levy M, Rhodes A, Annane D, Gerlach H, Opal S, Sevransky J, Sprung C, Douglas I, Jaeschke R, Osborn T, Nunnally M, Townsend S, Reinhart K, Kleinpell R, Angus D, Deutschman C, Machado F, Rubenfeld G, Webb S, Beale R, Vincent J-L, Moreno R. Surviving sepsis campaign: international guidelines for management of severe sepsis and septic shock, 2012. Intensive Care Med 39: 165-228, 2013.

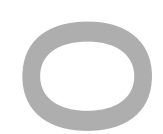

32. Denton KM, Anderson WP, Sinniah R. Effects of angiotensin II on regional afferent and efferent arteriole dimensions and the glomerular pole. Am J Physiol Regul Integr Comp Physiol 279: R629-R638, 2000.

33. Di Giantomasso D, May CN, Bellomo R. Norepinephrine and vital organ blood flow during experimental hyperdynamic sepsis. Intensive Care Med 29: 1774-1781, 2003.

This article is protected by copyright. All rights reserved 
34. Di Giantomasso D, Morimatsu H, Bellomo R, May C. Effect of low-dose vasopressin infusion on vital organ blood flow in the conscious normal and septic sheep. Anaesth Intensive Care 34: 427-433, 2006.

35. Dubin A, Pozo MO, Casabella CA, Pálizas F, Murias G, Moseinco MC, Kanoore Edul VS, Pálizas F, Estenssoro E, Ince C. Increasing arterial blood pressure with norepinephrine does not improve microcirculatory blood flow: a prospective study. Crit Care 13: R92-R92, 2009.

36. Dünser MW, Hasibeder WR. Sympathetic overstimulation during critical illness: Adverse effects of adrenergic stress. J Intensive Care Med 24: 293-316, 2009.

37. Eckardt K-U, Bernhardt WM, Weidemann A, Warnecke C, Rosenberger C, Wiesener MS, Willam C. Role of hypoxia in the pathogenesis of renal disease. Kidney Int 68: S46-S51, 2005.

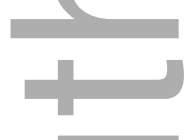

38. Evans R, Lankadeva Y, Cochrane A, Marino B, Iguchi N, Zhu M, Hood S, Smith J, Bellomo R, Gardiner B, Lee C, Smith D, CN M. Renal haemodynamics and oxygenation during and after cardiac surgery and cardiopulmonary bypass. Acta Physiol 222: e12995, 2018. 
39. Evans RG, Eppel GA, Anderson WP, Denton KM. Mechanisms underlying the differential control of blood flow in the renal medulla and cortex. $J$ Hypertens 22 : 1439-1451, 2004.

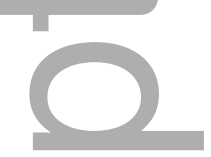

40. Evans RG, Gardiner BS, Smith DW, O'Connor PM. Intrarenal oxygenation: unique challenges and the biophysical basis of homeostasis. Am J Physiol Renal Physiol 295: F1259-F1270, 2008.

41. Evans RG, Ince C, Joles JA, Smith DW, May CN, O'Connor PM, Gardiner BS. Haemodynamic influences on kidney oxygenation: Clinical implications of integrative physiology. Clin Exp Pharmacol Physiol 40: 106-122, 2013.

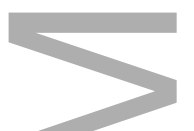

42. Fleischmann C, Scherag A, Adhikari N, Hartog C. Global sepsis incidence and mortality of hospital-treated sepsis. Am J Respir Crit Care Med 193: 259-272, 2016.

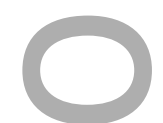

43. Geloen A, Chapelier K, Cividjian A, Dantony E, Rabilloud M, May CN, Quintin L. Clonidine and dexmedetomidine increase the pressor response to norepinephrine in experimental sepsis: A pilot study*. Crit Care Med 41: e431-e438 2013.

44. Gomez H, Ince C, De Backer D, Pickkers P, Payen D, Hotchkiss J, Kellum JA. A unified theory of sepsis-induced acute kidney injury: Inflammation, microcirculatory dysfunction, bioenergetics and the tubular cell adaptation to injury. Shock 41: 3-11, This article is protected by copyright. All rights reserved 
2014.

45. Gordon AC, Russell JA, Walley KR, Singer J, Ayers D, Storms MM, Holmes CL, Hébert PC, Cooper DJ, Mehta S, Granton JT, Cook DJ, Presneill JJ. The effects of vasopressin on acute kidney injury in septic shock. Intensive Care Med 36: 83-91, 2010.$$
\text { (1) }
$$

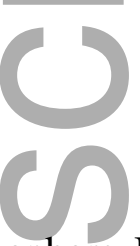

46. Greenberg JH, Coca S, Parikh CR. Long-term risk of chronic kidney disease and mortality in children after acute kidney injury: a systematic review. BMC Nephrol 15: $184,2014$.

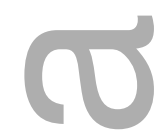

47. Hall JE. Historical perspective of the renin-angiotensin system. Mol Biotechnol 24: $27-39,2003$.

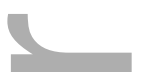

48. Hasser EM, Bishop VS. Reflex effect of vasopressin after blockade of V1 receptors in the area postrema. Circ Res 67: 265-271, 1990.

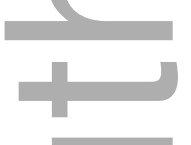

49. Heyman SN, Evans RG, Rosen S, Rosenberger C. Cellular adaptive changes in AKI: mitigating renal hypoxic injury. Nephrol Dial Transplant 27: 1721-1728, 2012.

50. Hofer S, Steppan J, Wagner T, Funke B, Lichtenstern C, Martin E, Graf B, Bierhaus A, Weigand M. Central sympatholytics prolong survival in experimental This article is protected by copyright. All rights reserved 
sepsis. Crit Care 13: R11, 2009.

51. Hollenberg SM. Vasopressor support in septic shock*. Chest 132: 1678-1687, 2007.

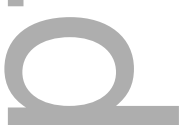

原

52. Holm L, Morsing P, Casellas D, Persson A. Resetting of the pressure range for blood flow autoregulation in the rat kidney. Acta Physiol Scand 138: 395-401, 1990.

53. Ikeoka K, Faber J. ANG II reverses selective inhibition of alpha 2-adrenoceptor sensitivity after in vitro isolation of arterioles. Am J Physiol Heart Circ Physiol 265: H1988-H1995, 1993.
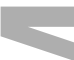

54. Ince C. The microcirculation is the motor of sepsis. Crit Care 9: S13-S19, 2005.

55. Jhanji S, Stirling S, Patel N, Hinds CJ, Pearse RM. The effect of increasing doses of norepinephrine on tissue oxygenation and microvascular flow in patients with septic shock*. Crit Care Med 37: 1961-1966, 2009.

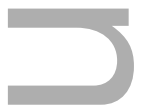

56. Johannes T, Mik EG, Nohé B, Raat NJH, Unertl KE, Ince C. Influence of fluid resuscitation on renal microvascular $\mathrm{PO}(2)$ in a normotensive rat model of endotoxemia. Crit Care 10: R88-R88, 2006. 
57. Kanoore Edul VS, Dubin A, Ince C. The microcirculation as a therapeutic target in the treatment of sepsis and shock. Semin Respir Crit Care Med 32: 558-568, 2011.

58. Kawazoe Y, Miyamoto K, Morimoto T, Yamamoto T, Fuke A, Hashimoto A, Koami H, Beppu S, Katayama Y, Itoh M, Ohta Y, Yamamura H. Effect of dexmedetomidine on mortality and ventilator-free days in patients requiring mechanical ventilation with sepsis: A randomized clinical trial. JAMA 317: 1321-1328, 2017.

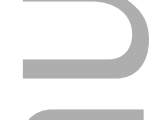

59. Kidney Disease: Improving Global Outcomes (KDIGO) Acute Kidney Injury Work Group. KDIGO clinical practice guideline for acute kidney injury. Kidney Int Suppl. 2: 1-138, 2012.

60. Kellum JA, Chawla LS, Keener C, Singbartl K, Palevsky PM, Pike FL, Yealy DM, Huang DT, Angus DC, for the Pro C, Pro G-AKII. The effects of alternative resuscitation strategies on acute kidney injury in patients with septic shock. Am J Respir Crit Care Med 193: 281-287, 2016.

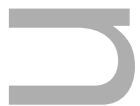

61. Kellum JA, Prowle JR. Paradigms of acute kidney injury in the intensive care setting. Nat Rev Nephrol 14: 217-230, 2018.

62. Khanna A, English SW, Wang XS, Ham K, Tumlin J, Szerlip H, Busse LW, This article is protected by copyright. All rights reserved 
Altaweel L, Albertson TE, Mackey C, McCurdy MT, Boldt DW, Chock S, Young PJ, Krell K, Wunderink RG, Ostermann M, Murugan R, Gong MN, Panwar R, Hästbacka J, Favory R, Venkatesh B, Thompson BT, Bellomo R, Jensen J, Kroll S, Chawla LS, Tidmarsh GF, Deane AM. Angiotensin II for the treatment of vasodilatory shock. $N$ Engl J Med 377: 419-430, 2017.

63. Kimmoun A, Ducrocq N, Levy B. Mechanisms of vascular hyporesponsiveness in septic shock. Curr Vasc Pharmacol 11: 139-149, 2013.

64. Kosaka J, Lankadeva YR, May CN, Bellomo R. The histopathology of septic acute kidney injury: A systematic review of experimental data. Crit Care Med 44: e897-903, 2016

65. Krejci V, Hiltebrand LB, Sigurdsson GH. Effects of epinephrine, norepinephrine, and phenylephrine on microcirculatory blood flow in the gastrointestinal tract in sepsis*. Crit Care Med 34: 1456-1463, 2006.

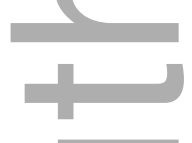

66. Landry DW, Oliver JA. The pathogenesis of vasodilatory shock. $N$ Engl J Med 345: 588-595, 2001.

67. Langenberg C, Bagshaw SM, May CN, Bellomo R. The histopathology of septic acute kidney injury: a systematic review. Crit Care 12: R38-R38, 2008.

This article is protected by copyright. All rights reserved 
68. Langenberg C, Bellomo R, May C, Wan L, Egi M, Morgera S. Renal blood flow in sepsis. Crit Care 9: R363-R374, 2005.

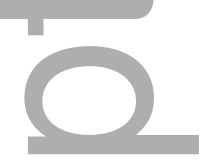

69. Langenberg C, Wan L, Egi M, May CN, Bellomo R. Renal blood flow in experimental septic acute renal failure. Kidney Int 69: 1996-2002, 2006.

70. Langenberg C, Wan L, Egi M, May CN, Bellomo R. Renal blood flow and function during recovery from experimental septic acute kidney injury. Intensive Care Med 33: 1614-1618, 2007.

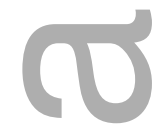

71. Lankadeva YR, Kosaka J, Evans R, Bellomo R, May C. Urinary oxygenation as a surrogate measure of medullary oxygenation during angiotensin II therapy in septic acute kidney injury. Crit Care Med 46: e41-e48, 2018.

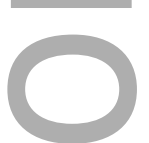

72. Lankadeva YR, Booth LC, Kosaka J, Evans RG, Quintin L, Bellomo R, May CN. Clonidine restores pressor responsiveness to phenylephrine and angiotensin II in ovine sepsis. Crit Care Med 43: e221-229, 2015.

73. Lankadeva YR, Kosaka J, Evans RG, Bailey M, Bellomo R, May CN. Intra-renal and urinary oxygenation during norepinephrine resuscitation in ovine septic acute kidney injury. Kidney Int 90: 100-108, 2016

This article is protected by copyright. All rights reserved 
74. Leech C, Faber J. Different alpha-adrenoceptor subtypes mediate constriction of arterioles and venules. Am J Physiol 270: H710-722, 1996.

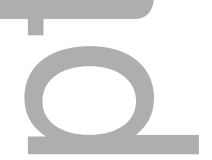

75. Legrand M, Mik E, Balestra G, Lutter R, Pirracchio R, Payen D, Ince C. Fluid resuscitation does not improve renal oxygenation during hemorrhagic shock in rats. Anesthesiology 112: 119-127, 2010.

76. Lerolle N, Nochy D, Guérot E, Bruneval P, Fagon J-Y, Diehl J-L, Hill G. Histopathology of septic shock induced acute kidney injury: apoptosis and leukocytic infiltration. Intensive Care Medicine 36: 471-478, 2010.

77. Leroy S, Aladin L, Laplace C, Jalem S, Rosenthal J-M, Abrial A, Quintin L. Introduction of a centrally anti-hypertensive, clonidine, reduces noradrenaline requirements in septic shock caused by necrotizing enterocolitis. Am J Emerg Med 35: e3-377, 2016.

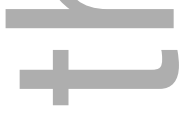

78. Levy B, Collin S, Sennoun N, Ducrocq N, Kimmoun A, Asfar P, Perez P, Meziani F. Vascular hyporesponsiveness to vasopressors in septic shock: from bench to bedside. Intensive Care Medicine 36: 2019-2029, 2010.

79. May CN, Calzavacca P, Ishikawa K, Langenberg C, Wan L, Ramchandra R, This article is protected by copyright. All rights reserved 
Bellomo R. Novel targets for sepsis-induced kidney injury: the glomerular arterioles and the sympathetic nervous system. Exp Physiol 97: 1168-1177, 2012.

80. May CN, Ishikawa K, Wan L, Williams J, Wellard RM, Pell GS, Jackson GD, Bellomo R. Renal bioenergetics during early gram-negative mammalian sepsis and angiotensin II infusion. Intensive Care Med 38: 886-893, 2012.

81. Morelli A, Ertmer C, Rehberg S, Lange M, Orecchioni A, Laderchi A, Bachetoni A, D'Alessandro M, Van Aken H, Pietropaoli P, Westphal M. Phenylephrine versus norepinephrine for initial hemodynamic support of patients with septic shock: a randomized, controlled trial. Crit Care 12: R143-R143, 2008.

82. Morelli A, Ertmer C, Westphal M, et al. Effect of heart rate control with esmolol on hemodynamic and clinical outcomes in patients with septic shock: A randomized clinical trial. JAMA 310: 1683-1691, 2013.

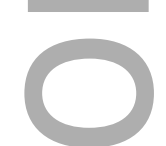

83. Mouncey PR, Osborn TM, Power GS, Harrison DA, Sadique MZ, Grieve RD, Jahan R, Harvey SE, Bell D, Bion JF, Coats TJ, Singer M, Young JD, Rowan KM. Trial of Early, Goal-Directed Resuscitation for Septic Shock. N Eng J Med 372: $1301-1311,2015$.

84. Murugan R, Karajala-Subramanyam V, Lee M, Yende S, Kong L, Carter M, Angus DC, Kellum JA. Acute kidney injury in non-severe pneumonia is associated This article is protected by copyright. All rights reserved 
with an increased immune response and lower survival. Kidney Int 77: 527-535, 2010.

85. Myburgh JA, Higgins A, Jovanovska A, Lipman J, Ramakrishnan N, Santamaria J. A comparison of epinephrine and norepinephrine in critically ill patients. Intensive Care Medicine 34: 2226-2234, 2008.
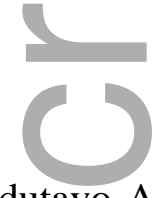

86. Odutayo A, Wong CX, Farkouh M, Altman DG, Hopewell S, Emdin CA, Hunn

BH. AKI and long-rerm risk for cardiovascular events and mortality. J Am Soc Nephrol 28: 377-387, 2017.

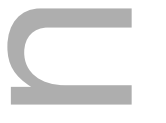

87. Pandharipande P, Sanders R, Girard T, McGrane S, Thompson J, Shintani A, Herr

D, Maze M, Ely EW, investigators tM. Effect of dexmedetomidine versus lorazepam on outcome in patients with sepsis: an a priori-designed analysis of the MENDS randomized controlled trial. Crit Care 14: R38, 2010.

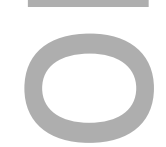

88. Peake S, Delaney A, Bailey M, Bellomo R, Cameron P, Cooper D, Higgins A, Holdgate A, Howe B, Webb S, Williams P. Goal-directed resuscitation for patients with early septic shock. N Eng J Med 371: 1496-1506, 2014.

89. Pichot C, Ghignone M, Quintin L. Dexmedetomidine and clonidine: From secondto first-line sedative agents in the critical care setting? J Intensive Care Med 27: 219-237, 2012.

This article is protected by copyright. All rights reserved 
90. Pichot C, Mathern P, Khettab F, Ghignone M, Geloen A, Quintin L. Increased pressor response to noradrenaline during septic shock following clonidine? Anaesth Intensive Care 38: 784-785, 2010.

91. Pollard S, Edwin SB, Alaniz C. Vasopressor and inotropic management of patients with septic shock. Pharmacy and Therapeutics 40: 438-450, 2015.

92. Post EH, Kellum JA, Bellomo R, Vincent J-L. Renal perfusion in sepsis: from macro- to microcirculation. Kidney Int 91: 45-60, 2016.

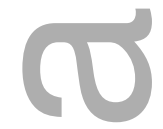

93. Rajapakse NW, Roman RJ, Falck JR, Oliver JJ, Evans RG. Modulation of V1-receptor-mediated renal vasoconstriction by epoxyeicosatrienoic acids. Am J Physiol Regul Integr Comp Physiol 287: R181-R187, 2004.

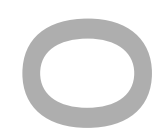

94. Reade M, Eastwood G, Bellomo R, Bailey M, Bersten A, Cheung B, Davies A, Delaney A, Ghosh A, van Haren F, Harley N, Knight D, McGuiness S, Mulder J, O'Donoghue S, Simpson N, Young P, Investigators D, Group AaNZICSCT. Effect of dexmedetomidine added to standard care on ventilator-free time in patients with agitated delirium: A randomized clinical trial. JAMA 315: 1460-1468, 2016.

95. Rector F, S. G, Rosenberg I, Lucas C. Sepsis: a mechanism for vasodilation in the This article is protected by copyright. All rights reserved 
1973.

96. Rhodes A, Evans LE, Alhazzani W, Levy MM, Antonelli M, Ferrer R, Kumar A, Sevransky JE, Sprung CL, Nunnally ME, Rochwerg B, Rubenfeld GD, Angus DC, Annane D, Beale RJ, Bellinghan GJ, Bernard GR, Chiche J-D, Coopersmith C, De Backer DP, French CJ, Fujishima S, Gerlach H, Hidalgo JL, Hollenberg SM, Jones AE, Karnad DR, Kleinpell RM, Koh Y, Lisboa TC, Machado FR, Marini JJ, Marshall JC, Mazuski JE, McIntyre LA, McLean AS, Mehta S, Moreno RP, Myburgh J, Navalesi P, Nishida O, Osborn TM, Perner A, Plunkett CM, Ranieri M, Schorr CA, Seckel MA, Seymour CW, Shieh L, Shukri KA, Simpson SQ, Singer M, Thompson BT, Townsend SR, Van der Poll T, Vincent J-L, Wiersinga WJ, Zimmerman JL, Dellinger RP. Surviving sepsis campaign: International guidelines for management of sepsis and septic shock: 2016. Intensive Care Med 43: 304-377, 2017.

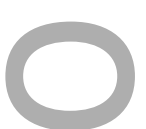

97. Russell JA. Bench-to-bedside review: Vasopressin in the management of septic shock. Crit Care 15: 226-226, 2011.

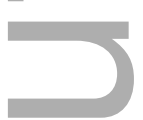

98. Russell JA, Walley KR, Singer J, Gordon AC, Hébert PC, Cooper DJ, Holmes CL, Mehta S, Granton JT, Storms MM, Cook DJ, Presneill JJ, Ayers D. Vasopressin versus norepinephrine infusion in patients with septic shock. N Engl J Med 358: 877-887, 2008.

This article is protected by copyright. All rights reserved 
99. Schrier RW, Wang W. Acute renal failure and sepsis. N Engl J Med 351: 159-169, 2004.

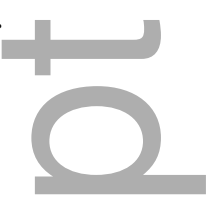

100. Sharma V, Dellinger RP. The International Sepsis Forum's frontiers in sepsis: high cardiac output should not be maintained in severe sepsis. Crit Care 7: 272-275, 2003.

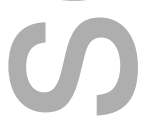

101. Singer M, Deutschman CS, Seymour C, Shankar-Hari M, Annane D, Bauer M, Bellomo R, et al. The third international consensus definitions for sepsis and septic shock (sepsis-3). JAMA 315: 801-810, 2016.

102. Sorensen C, Leyssac P, Skott O, Holstein-Rathlou N. Role of the renin-angiotensin system in regulation and autoregulation of renal blood flow. Am J Physiol Regul Integr Comp Physiol 279: R1017-R1024, 2000.

103. Souza ACP, Yuen PST, Star RA. Microparticles: markers and mediators of sepsis-induced microvascular dysfunction, immunosuppression, and AKI. Kid Int 87: $1100-1108,2015$.

104. Takasu O, Gaut JP, Watanabe E, To K, Fagley RE, Sato B, Jarman S, Efimov IR, Janks DL, Srivastava A, Bhayani SB, Drewry A, Swanson PE, Hotchkiss RS. Mechanisms of cardiac and renal dysfunction in patients dying of sepsis. Am J Respir This article is protected by copyright. All rights reserved 
Crit Care Med 187: 509-517, 2013.

105. Taniguchi T, Kidani Y, Kanakura H, Takemoto Y, Yamamoto K. Effects of dexmedetomidine on mortality rate and inflammatory responses to endotoxin-induced shock in rats. Crit Care Med 32: 1322-1326 2004.

106. Taniguchi T, Kurita A, Kobayashi K, Yamamoto K, Inaba H. Dose- and time-related effects of dexmedetomidine on mortality and inflammatory responses to endotoxin-induced shock in rats. J Anesth 22: 221-228, 2008.

107. Tumlin J, Murugan R, Deane A, R B. Outcomes of patients with vasodilatory shock and renal replacement therapy treated with intravenous angiotensin II. Crit Care Med 46: 949-957, 2018.

108. Wan L, Langenberg C, Bellomo R, May C. Angiotensin II in experimental hyperdynamic sepsis. Crit Care 13: R190, 2009.

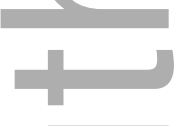

109. Yealy D, Kellum J, Huang D, Barnato A, Weissfeld L, Pike F, Terndrup T, Wang H, Hou P, LoVecchio F, Filbin M, Shapiro N, Angus D. A randomized trial of protocol-based care for early septic shock. N Eng J Med 370: 1683-1693, 2014. 


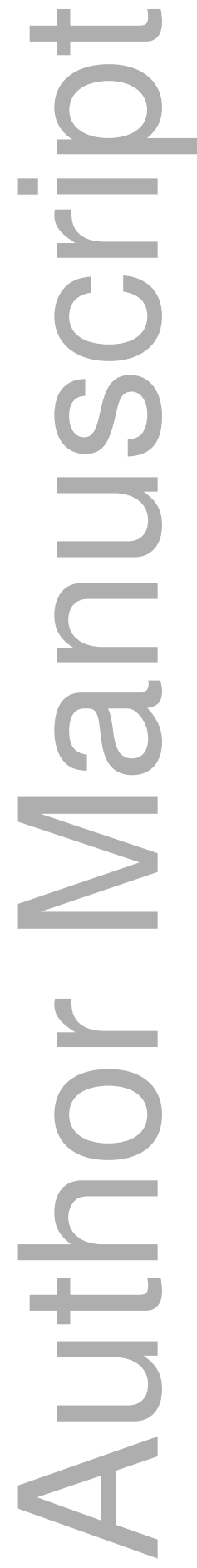

This article is protected by copyright. All rights reserved 

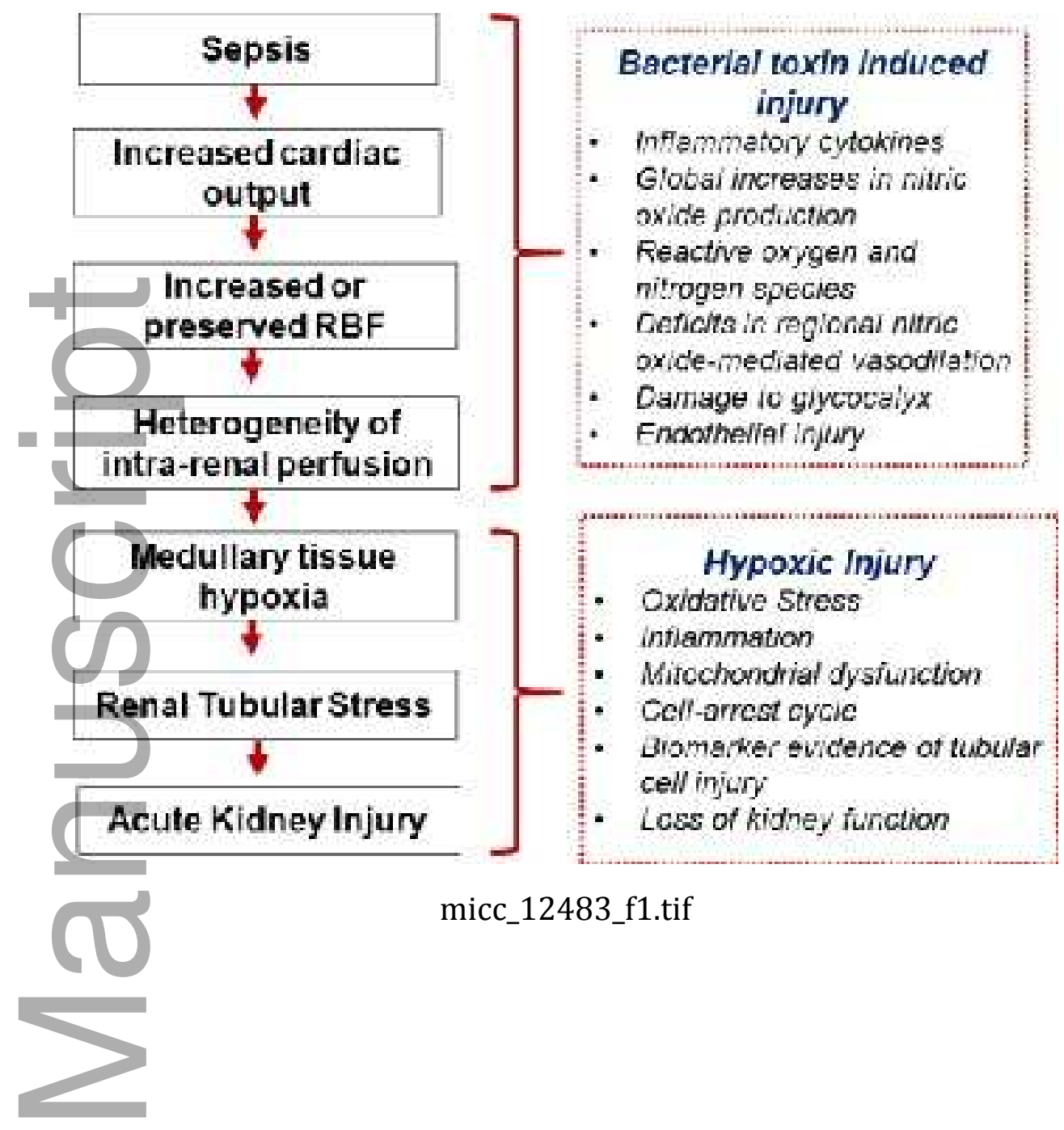

micc_12483_f1.tif

This article is protected by copyright. All rights reserved 


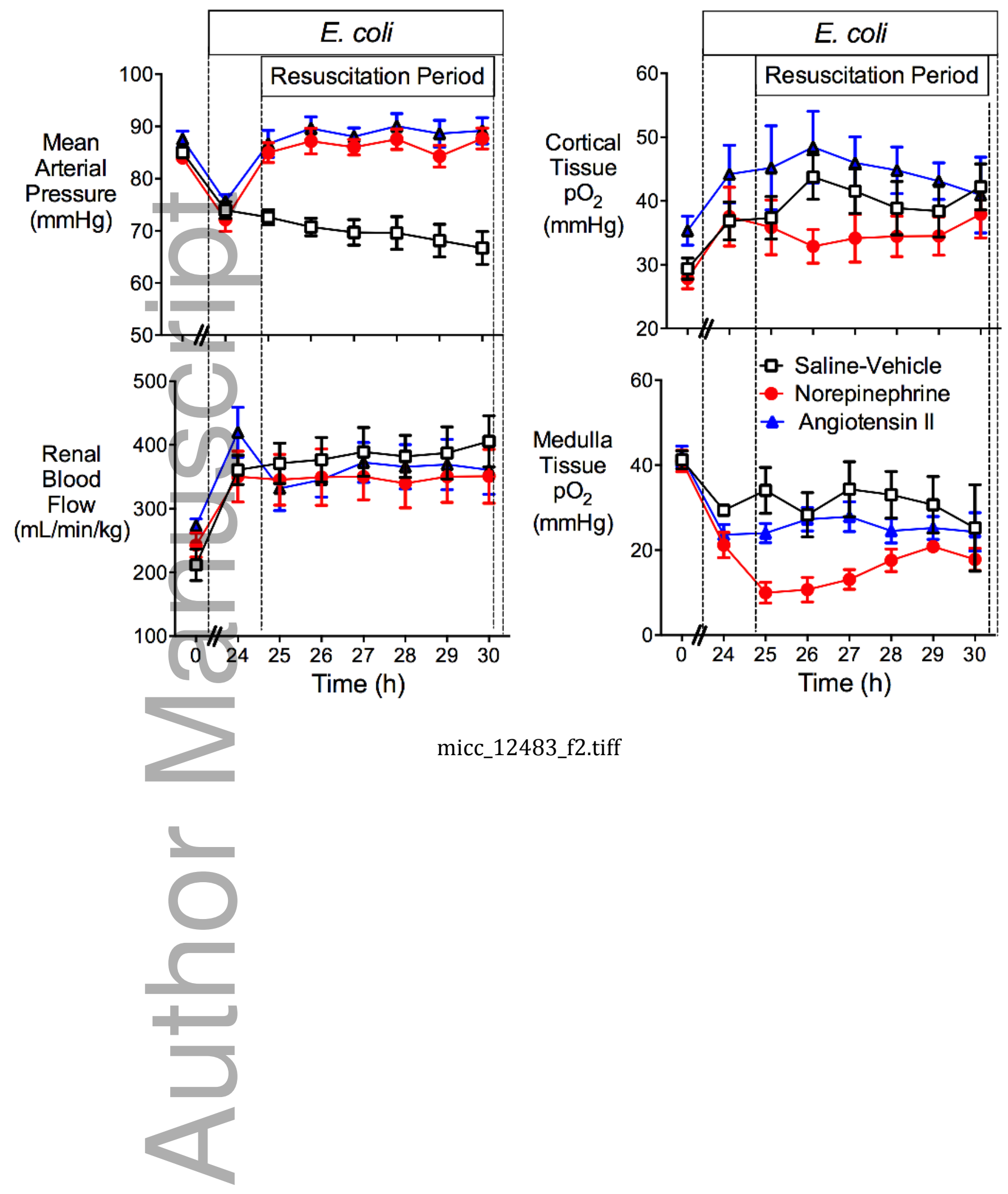

This article is protected by copyright. All rights reserved 


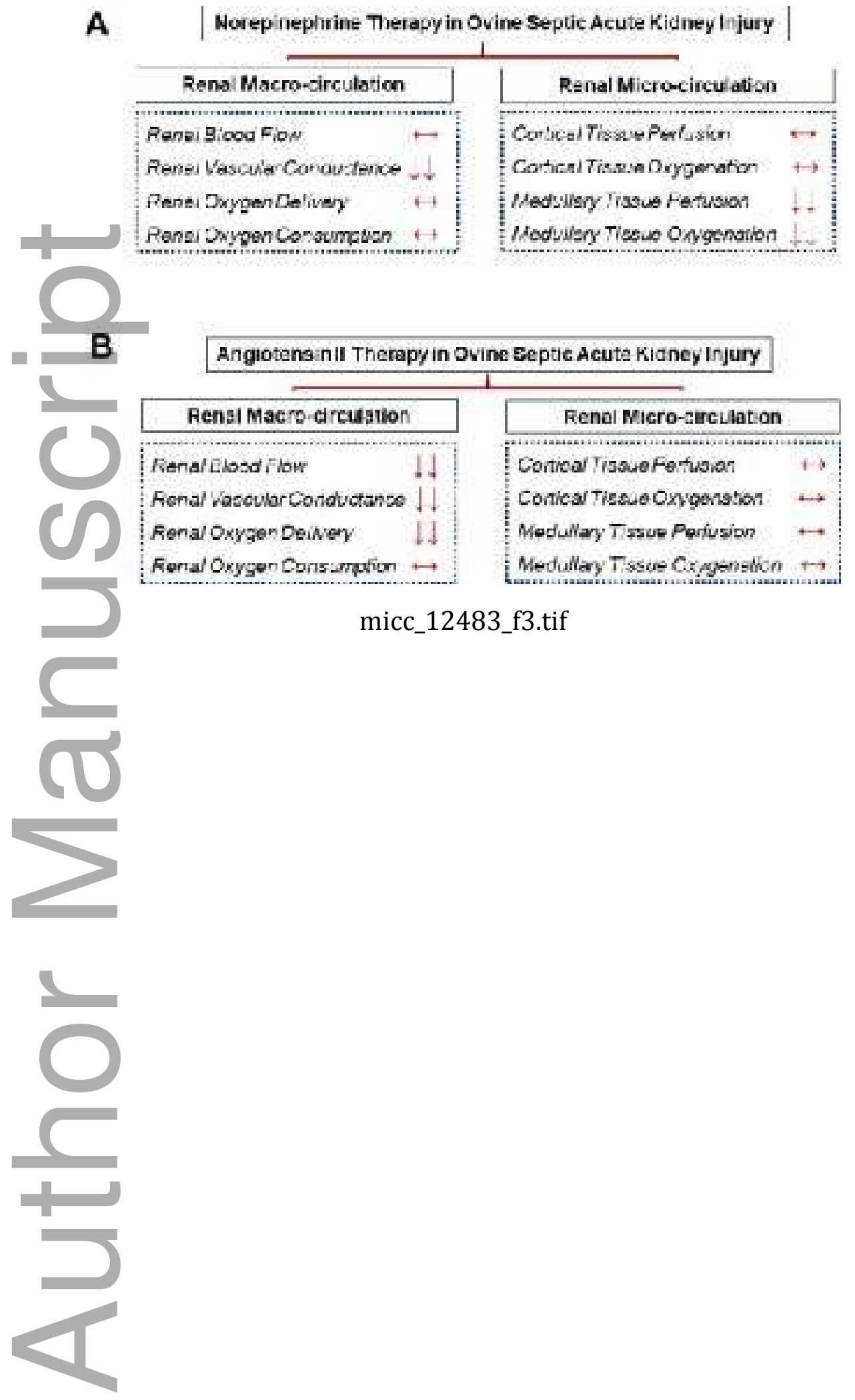

This article is protected by copyright. All rights reserved 


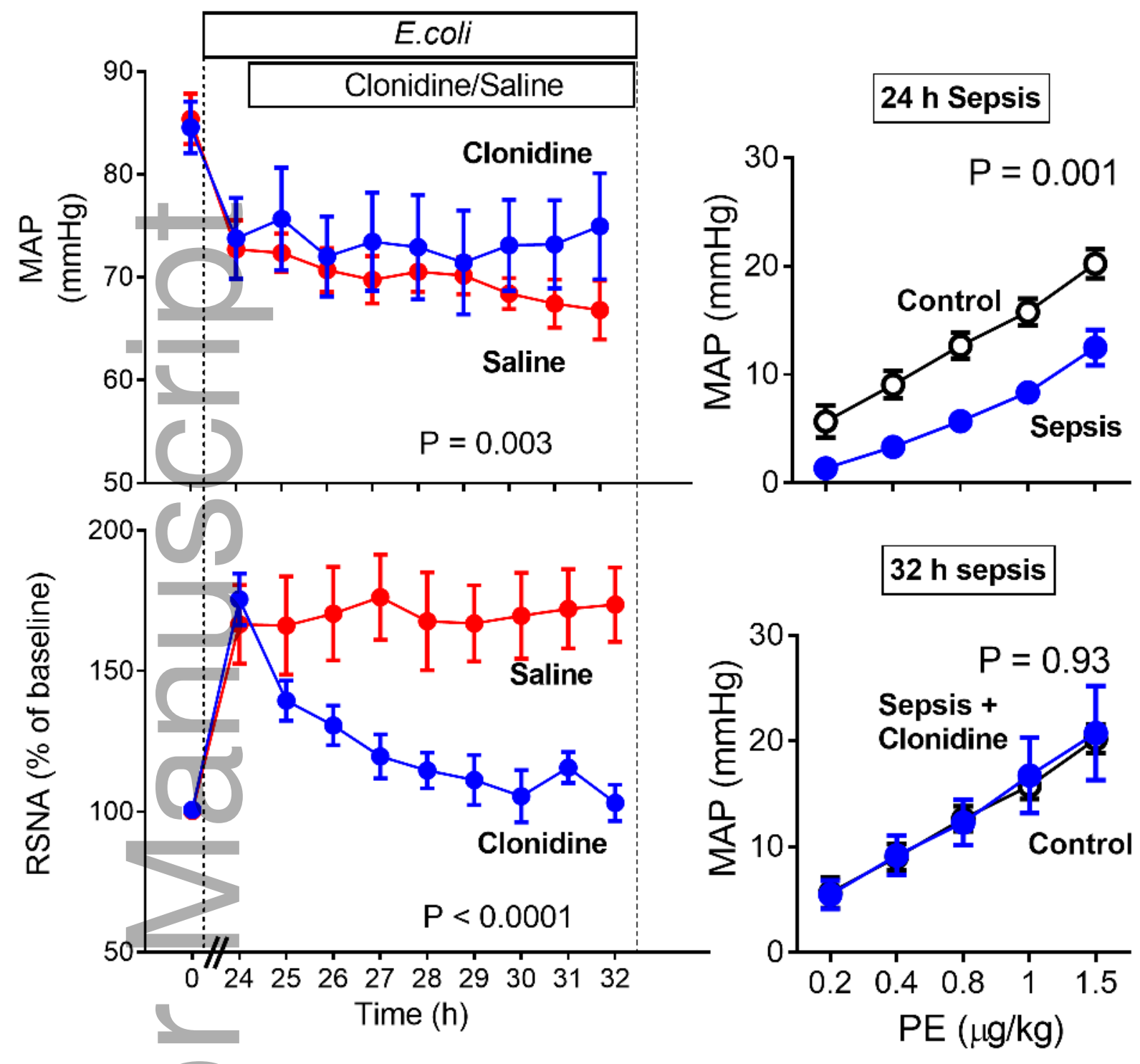

micc_12483_f4.tif 


\section{University Library}

\section{- M M N E R VA A gateway to Melbourne's research publications}

Minerva Access is the Institutional Repository of The University of Melbourne

Author/s:

Ma, S;Evans, RG;Iguchi, N;Tare, M;Parkington, HC;Bellomo, R;May, CN;Lankadeva, YR

Title:

Sepsis-induced acute kidney injury: A disease of the microcirculation

Date:

2019-02-01

Citation:

Ma, S., Evans, R. G., Iguchi, N., Tare, M., Parkington, H. C., Bellomo, R., May, C.

N. \& Lankadeva, Y. R. (2019). Sepsis-induced acute kidney injury: A disease of the microcirculation. MICROCIRCULATION, 26 (2), https://doi.org/10.1111/micc.12483.

Persistent Link:

http://hdl.handle.net/11343/284183 